\title{
INFLUENCE OF THE KNOWLEDGE ECONOMY ON THE ECONOMIC GROWTH AND ECONOMIC LEVEL OF THE COUNTRIES
}

\author{
[Vliv znalostní ekonomiky na ekonomický růst a ekonomickou úroveň zemí] \\ Irena Paličková ${ }^{1}$ \\ ${ }^{I}$ Vysoká škola báňská-Technická univerzita Ostrava, Ekonomická fakulta, Sokolská tř́ida 33, 70121 Ostrava \\ Email:irena.palickova@vsb.cz
}

\begin{abstract}
The article deals with the analysis of the relationship between knowledge economy and economic growth and economic level of the countries. Concept of knowledge economy and its growth is defined in the first two chapters. Then two hypotheses about positive relationship between knowledge economy and economic level and knowledge economy and economic growth are verified at the group of the world economy countries. For verification of the both hypotheses is used regression analysis. The first hypothesis was confirmed. It holds for the group of world economy countries that the more investments in knowledge the country has, the more advanced is and vice versa. Also strong correlation between economic level of the country and each part of the knowledge economy index, i. e economic and institutional regime, education, innovation and information and communication technologies, was proved. On the contrary the second hypothesis was not confirmed. It does not hold that knowledge economy will lead to higher economic growth in future. Surprisingly it was found that relationship between these two variables is negative.
\end{abstract}

Keywords: economic growth, economic level, knowledge economy, knowledge economy index, regression analysis, world economy countries.

JEL classification: F43

Doručeno redakci: 22.5.2013; Recenzováno: 14.6.2013; 20.6.2013; Schváleno k publikování: 23.9.2014

\section{Introduction}

The competitiveness of the national economies depends more and more on their capacity to produce and use knowledge. Knowledge, education, information and innovation are the main indicators of the economic growth at the globalization process. Knowledge importance for economic growth is deepened by the late economic depression, which interfered with the all European (developed) countries. They have big problems with their fiscal deficits and growing government debts. The competitiveness of European countries is based on the technological progress and quality in contrast to the developing countries that have their comparative advantage in lower input prices especially labour force. Technological progress depends on the access to more knowledge and information. The concept of knowledge economy is used more often nowadays. In this economy new technology infrastructure, research, innovation and education are interconnected.

The aim of this article is to define relation between knowledge economy as well as human capital and economic growth and economic level of the countries. The two hypotheses are verified in this article:

More advanced countries invest in knowledge more than less advanced countries, therefore the more investments in knowledge the country has, the more advanced is and ice versa, ceteris paribus. 
Knowledge economy is indicator of economic growth that means the more economy invests in knowledge, the higher rate of economic growth it will have in future, ceteris paribus.

All countries of the world economy that are in the database of the World Bank are investigated. The relationship between knowledge economy and economic level of the country is examined on the group of 139 countries, while the relationship between knowledge economy and economic growth only on the sample of 114 countries according to data availability. Knowledge is measured by the KEI (Knowledge Economy Index), which is defined by the World Bank too. Economic growth means the rate of growth of GDP per worker during period of 2001-2011. Economic level of the country is measured by GDP per capita in current international dollars. According to this value, the countries are divided into four groups in step with the World Bank classification - high income (USD 12,276 or more), upper middle income (USD 3,976-12,275), lower middle income (USD 1,006-3,975) and low income countries (USD 1,005 or less). Cross-country comparison and regression analyses are used to find out results.

\section{Knowledge economy concept}

„The major changes in the last years - the exponential growth of investments in knowledge, mobile communications and internet users - accelerated development of new economy. In fact, in this economy, knowledge has become the key driver of economic competitiveness and success: it has added massive value to economic production through increases in productivity and the application of new technologies and new ideas - both in the forms of new inventions and also new applications of existing knowledge - has brought revolutionary chase to virtually all markets and sectors. " ${ }^{1}$ Knowledge economy is in this article defined according to the approach of the World Bank, which set up Knowledge Assessment Methodology (KAM) that describes Knowledge Economy Index and Knowledge Index. „Knowledge Index (KI) measures a country's ability to generate, adopt and diffuse knowledge. This is an indication of overall potential of knowledge development in a given country. Knowledge Economy Index (KEI) takes into account whether the environment is conducive for knowledge to be used effectively for economic development. It is an aggregate index that represents the overall level of development of a country or region towards the Knowledge Economy." ${ }^{2}$ KEI consists of four subindexes - economic and institutional regime, education and human resources, the innovation system and ICT.

\footnotetext{
${ }^{1}$ BATAGAN, L. Knowledge Dynamics and Economy Growth. Revista Informatica Economica [online]. Nr. 4(48), 2008, pp. 27-30. Available from: http://revistaie.ase.ro/content/48/BATAGAN\%20Lorena.pdf [cit. 201302-26].

${ }^{2}$ WORLD BANK INSTITUTE. Measuring knowledge in the world's economies. Knowledge for development program [online]. Available from: http://siteresources.worldbank.org/INTUNIKAM/Resources/KAM_v4.pdf [cit. 2013-03-10].
} 
Figure 1: Structure of the Knowledge Economy Index

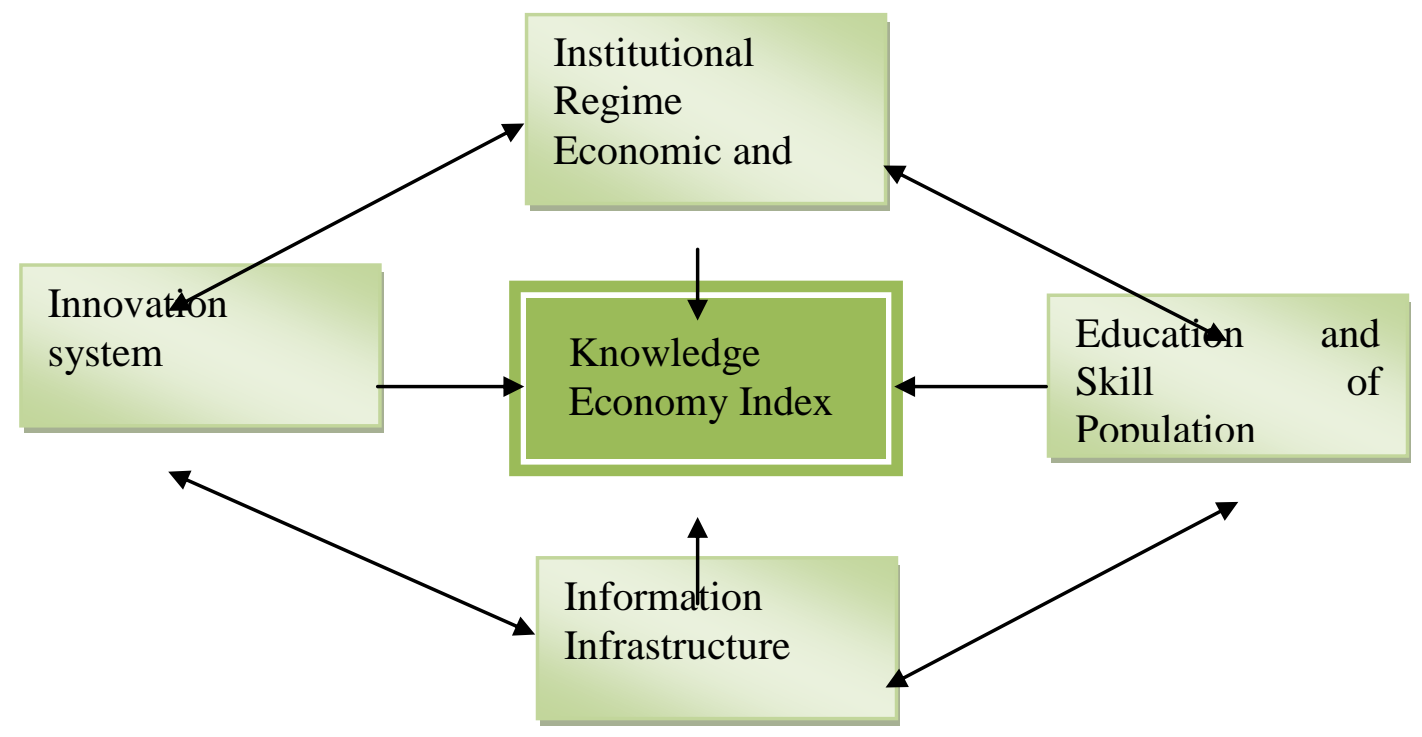

Source: own elaboration

Overall performance of economy is looked on the rate of GDP growth, GDP per capita, absolute GDP, human development index, employment rate or unemployment rate. Subindex economic and institutional regime takes in tariff and nontariff barriers used in international trade, regulatory quality measured for example by falls of the price regulation or inadequate bank supervision falls or factor reducing doing business. We can mention here also rule of law, judiciary efficiency, contract enforcement etc. The education and human resources area includes average years of schooling, secondary enrolment, tertiary enrolment, rate of literacy of adults older 15 years or public expenditures for education as percentage of GDP. The sphere of innovation includes following royalty and licence fees payments and receipts, patent applications granted by the US Patent and Trademark Office and scientific a technical journal articles, total expenditures for research and development as percentage of GDP and rate of cooperation between universities and business firms. Key indicators measuring ICT area are numbers of telephones per 1000 people, computers per 1000 people, internet users per 1000 people or total expenditures for ICT as percentage of GDP.

All the mentioned variables help to find out whether or to what extent a country uses knowledge for its overall economic and social development. Knowledge economy index can reach value from scale of 0 to 10 (10 is the best value) at two versions, weighted or unweighted by population. Both the indexes have more predicated ability in cross-country or over-time comparison.

\section{Economic growth concept in knowledge economy}

Knowledge, information or new economy mean the growing importance of human capital for economic growth. Human capital (education and qualification of the labour force) replaced the main factors of economic growth - capital and labour - and has become its most important indicators. The change of the conception of human capital on economic growth has shown in the theory of economic growth and has led to creation of new growth theory in the eighties of the 20 century. Neo-classic growth theories undervalued the importance of capital because return from human capital put down to labour and reduced share of capital in income this way. According to the new growth theories it is necessary to implicate its tangible and 
intangible forms in capital. Getting knowledge and skills by way of qualification and education rating is one of very important forms of its accumulation.

Human capital has become the least mobile component of the producing fiction and it is one of the reasons why education has become key variable in the equation explaining differences in the competitiveness of the national economies. The increasing of the human capital investments influences the growth of productivity of labour. Higher education is very important source of economic growth and promotively acts on the efficiency of the others factors of economic growth, for example on utilization of effects of technological progress, production control and organization etc. The value of human capital is growing because of ability to produce more and more goods and services but also because of ability to produce superior goods or services. The importance of human capital for the development of competitiveness of the national economy is growing because human capital is much more resistant to total globalization of conditions of the economic growth, compared to the other factors in production function.

Figure 2: Factors of knowledge economy determining economy growth

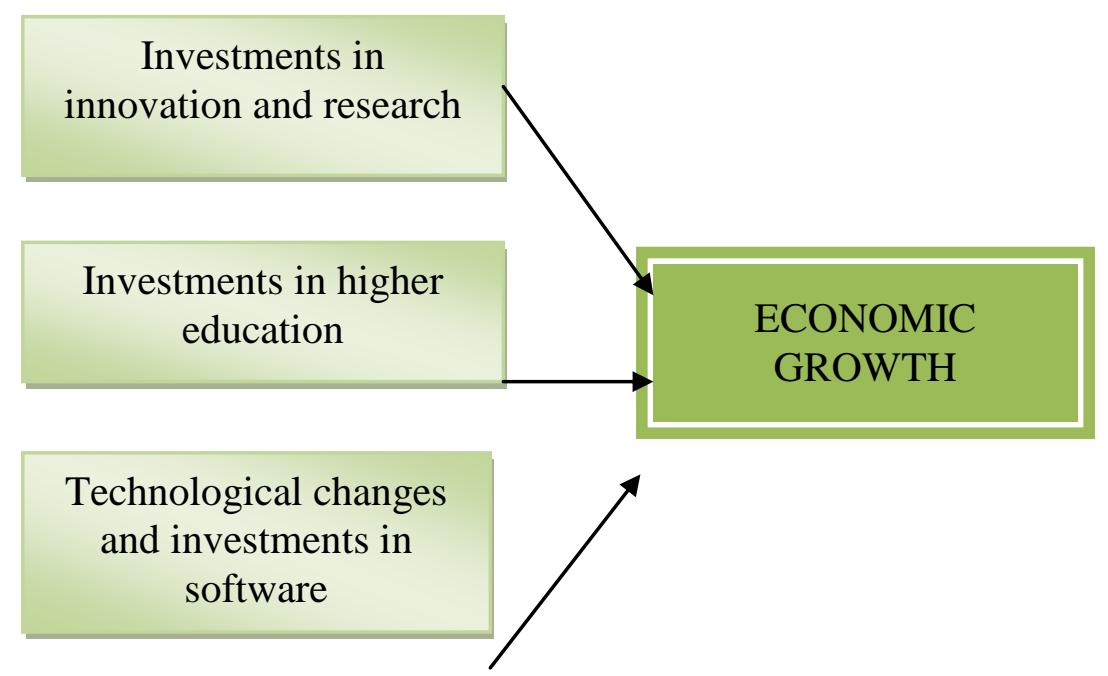

Source: own elaboration

According to a newly published paper of OECD ,increasing of average number years of the decent education about one year means growing of the economic performance per capita about $6 \%$. In the developing countries this growth is connected with the growth of the people with primary and secondary education primarily, while in the advanced countries of OECD the expansion of the tertiary education is this factor."3

Harberger, an analyst of the economic growth indicators, diversifies two types of influences of the higher education on economic growth. The first type he compares to the effect of yeast: „knowledge and human capital rise level of the overall economy more or less equally, analogon to proofing dough, to which yeast is added." ${ }^{4}$ The second effect he likens to

\footnotetext{
3 MATĚJŮ, P. Vzdělání a hospodářský růst. Institut pro sociální a ekonomické analýzy. [online], 5. 9. 2001. Available from: http://www.isea-cz.org/Aktuality/Posledn\%C3\%AD\%C4\%8D1\%C3\%A1nkyakoment\%C3\% A1\%C5\%99e/tabid/64/articleType/ArticleView/articleId/440/Vzdln-a-hospodsk-rst.aspx [cit. 2013-03-18]

${ }^{4}$ Ibidem
} 
mushrooms, that „suddenly grow up there, where extra suitable conditions were for it. “ ${ }^{5}$ It is case when some discovery or innovation lead to the huge growth of productivity.

Investments in human capital also lead to the higher productivity of labour, innovation, higher quality of work and above-average yields. Individuals and government are two basic groups of investors because investments into human capital implicate fairly valuable positive externality too.

\section{Relation between knowledge economy and economic level of the country}

Economic level and knowledge are interconnected. The relation between knowledge accumulation measuring by KEI and economic level was under review at the file of 139 countries. In fact, the correlation between the accumulation of knowledge and levels of economic development is around $81 \%$, the model is statistically significant at the $5 \%$ level of significance $(\mathrm{p}$-value $=4,35 \mathrm{E}-34)$. Countries with higher KEI values tend to have higher levels of economic development and vice versa. The running of regression line is represented in picture 1. The horizontal axis plots countries' KEI scores for 2012. The vertical axis plots the same countries' GDP per capita for 2010 in current international dollars. This positive correlation does not establish a causal relationship between the KEI and economic development. „In fact, it is very plausible that high-income countries, because they are more affluent, are able to afford more investments in knowledge. The correlation, by itself does not permit us to predict with any degree of certainly that building up certain forms of knowledge in a poor country will be sure to produce economic growth anytime soon." 6

Figure 3: Relationship between KEI and economic level

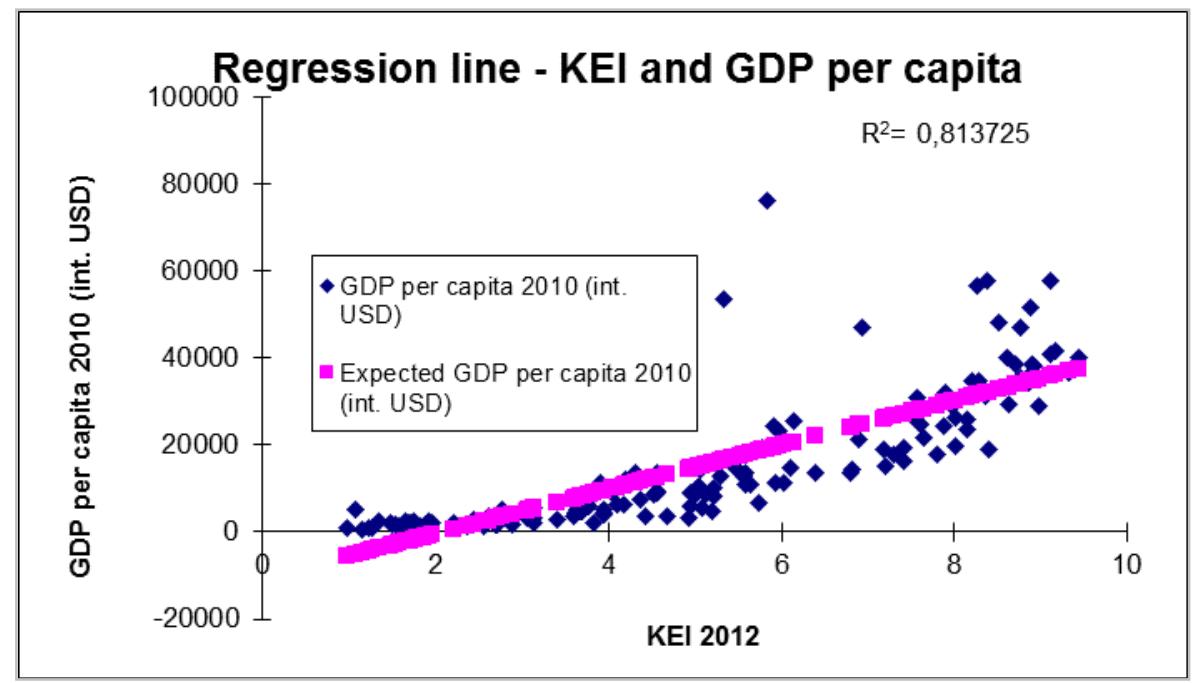

Source: www.worldbank.org, own elaboration

As to various pillars of the knowledge economy, it is possible to state that the highest correlation is between level of economic level and innovation, the second is pillar ICT, then pillar of economic and institutional regime and the lowest correlation is between economic level and education. Running of the regression lines as well as summary of regression coefficients are shown in figure 4 . All the variables are statistically significant at the 5\% level of significance.

\footnotetext{
${ }^{5}$ Ibidem

${ }^{6}$ WORLD BANK INSTITUTE. Measuring knowledge in the world's economies. Knowledge for development program [online]. Available from: http://siteresources.worldbank.org/INTUNIKAM/Resources/KAM_v4.pdf [cit. 2013-03-10]
} 
Figure 4: Regression lines and regression coefficients for pillars of knowledge economy index
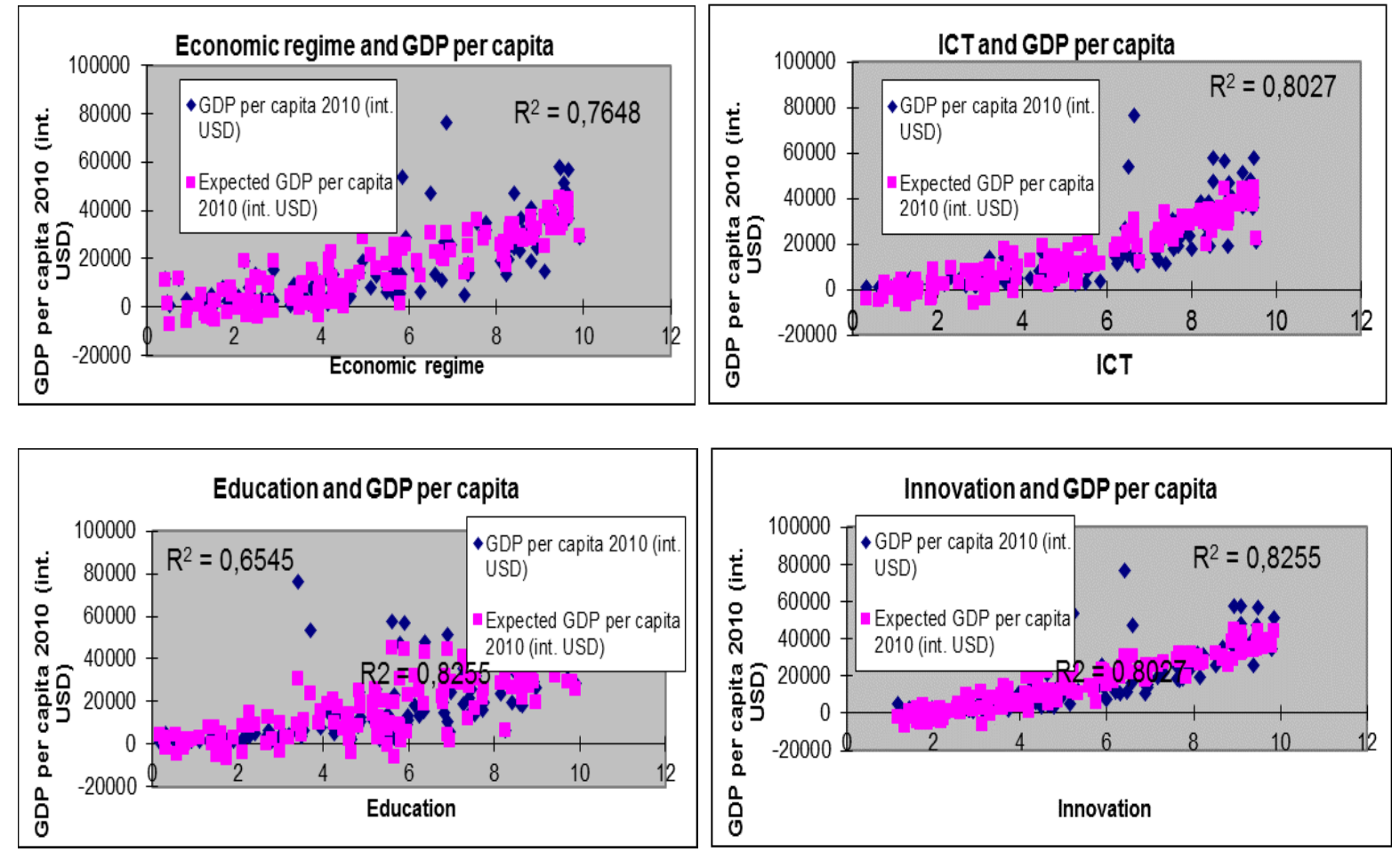

Source: www.worldbank.org, own elaboration

The position of particular groups of the countries in 12 key variables of all pillars of the KEI is evident from the picture 5. You can see that the World Bank does not publish all variables and results can be inaccurate. The rank of these groups according to fruitfulness is following: high income, upper middle income, lower income and low income countries. According to reasonable data we can say that high income countries have the best position in the number of patents granted by USPTO/million people and in number of internet users per 1000 people. The upper middle income countries are the best as to number of total telephones and internet users per 1000 people. The same result can be found in the group of lower middle income countries. Values in the group of the low countries are the lowest for the all variables.

Figure 5: Structure of the KEI for particular groups of countries

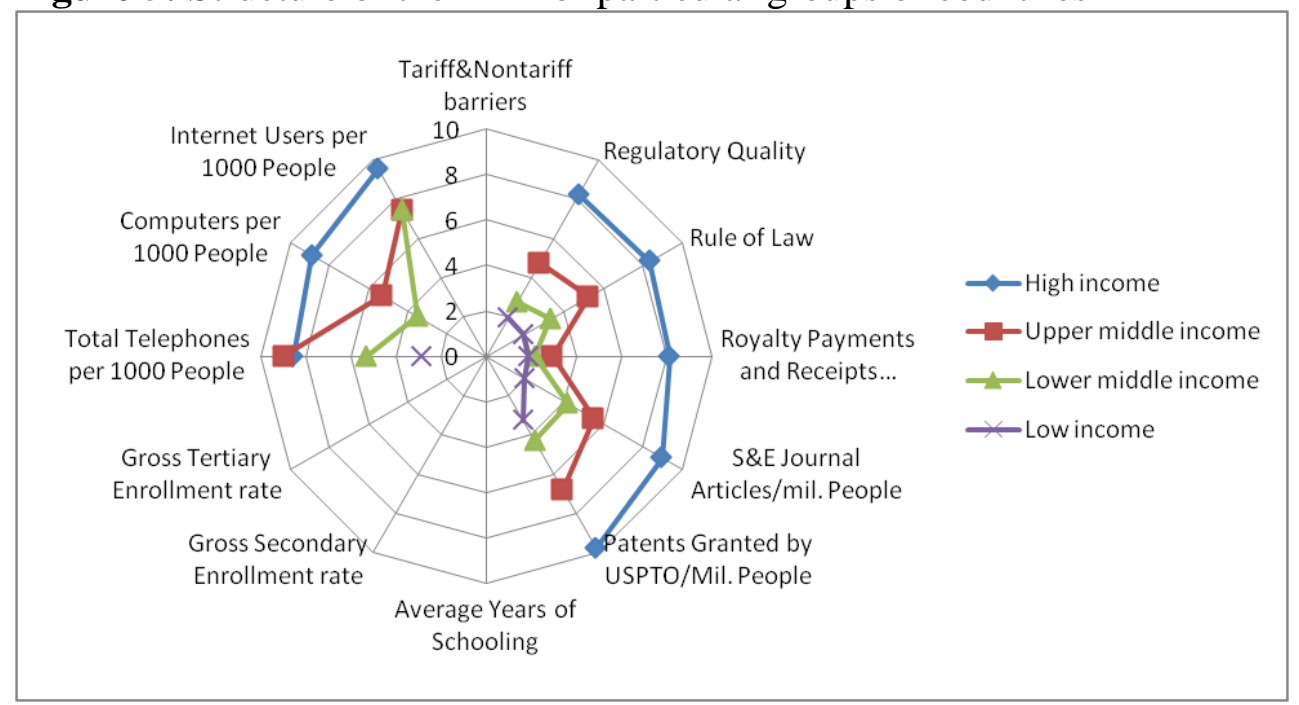

Source: www.worldbank.org 


\section{Knowledge economy and economic growth}

„Investment in innovation, research, education and technological changes have the most central point to economic performance. The growth of economy can be analyzed by the investments in higher education, innovation and research, and software. ${ }^{67}$ It is said that higher KEI values are associated with higher rates of future economic growth (with other factors held constant). Figure 6 illustrates the relation between countries' KEI values and their average future growth rates of output per worker. The horizontal axis plots countries' KEI scores for 2000. The vertical axis plots the same countries' annual growth in output per worker, averaged over the years 2001-2011. Surprisingly regression line falls, regression coefficient is very low, and correlation coefficient is negative. All of it does not confirm the second hypothesis. From the model results that knowledge economy is not key source of economic growth and the role of knowledge or informative or new economy in the economic performance of the countries is overvalued.

Václav Klaus has the same pessimistic opinion of knowledge economy. He said at the conference with title „Knowledge industrial sectors and now technologies“ in Rijád: „As an economist I believe in the efficiency of the actual market economy and do not believe in upto-date adjective, which is added to it - such as socio-market economy or informative or knowledge economy. Recent depression has provided another clear signal in this respect. At least in Europe it holds that countries that kept up up-to-date allurements of deindustrialization, dealt with the depression much better than countries that relied on the sector of services and on the state-of-the-art and the most complicated technologies' supporting. A solid and widely furcate industrial base peered to be indisputable advantage. “8

Figure 6: Relation between KEI and average economic growth

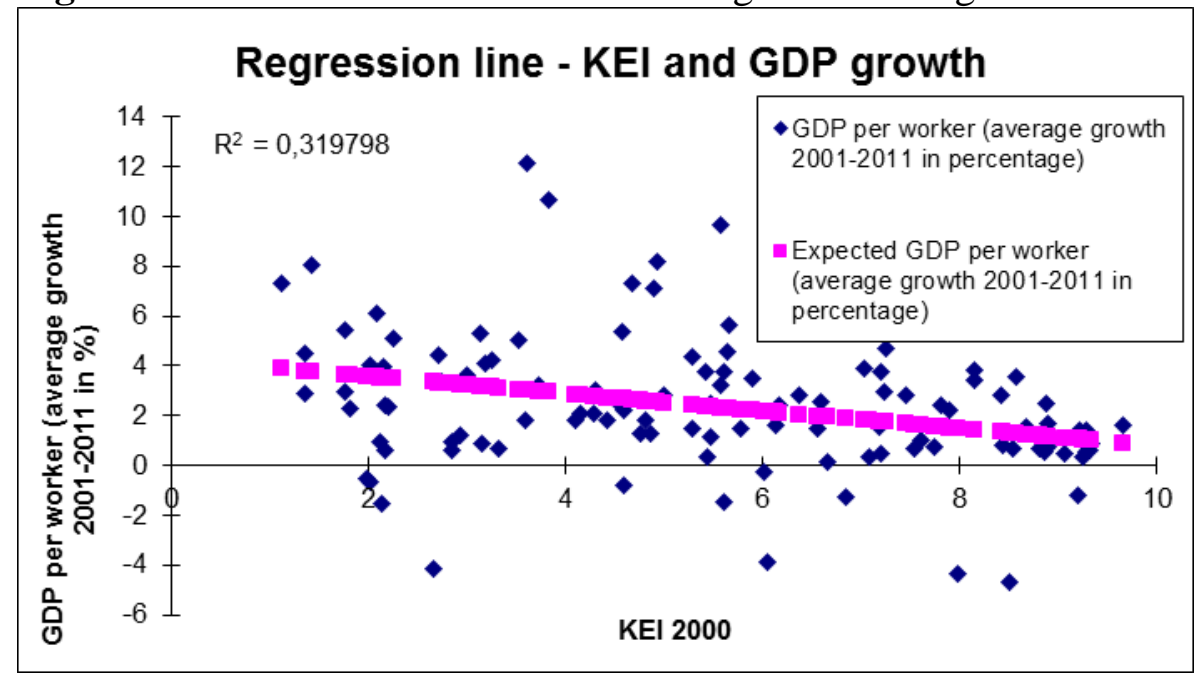

Source: www.worldbank.org, own elaboration

This relationship was also examined in particular income groups of countries and was realized whether this relationship is stronger in the high income countries than in the low income countries or not. The results are summarized in the table 1 . The relationship is positive only in the groups of high income countries and lower middle income countries, but its values are low enough to deduce general conclusion.

\footnotetext{
7 BATAGAN, L. Knowledge Dynamics and Economy Growth. Revista Informatica Economica [online]. Nr. 4(48), 2008, pp. 27-30. Available from: http://revistaie.ase.ro/content/48/BATAGAN\%20Lorena.pdf [cit. 201302-26]

${ }^{8}$ KLAUS, V. Jak je to $s$ "vědomostni" ekonomikou? Lidové noviny, 18. 1. 2012
} 
Table 1: Coefficients of regression function for income groups of countries

\begin{tabular}{|l|l|l|l|l|l|}
\hline $\begin{array}{l}\text { KEI and economic } \\
\text { growth }\end{array}$ & $\begin{array}{l}\text { All } \\
\text { countries }\end{array}$ & $\begin{array}{l}\text { High income } \\
\text { countries }\end{array}$ & $\begin{array}{l}\text { Upper middle } \\
\text { income } \\
\text { countries }\end{array}$ & $\begin{array}{l}\text { Lower middle } \\
\text { income } \\
\text { countries }\end{array}$ & $\begin{array}{l}\text { Low income } \\
\text { countries }\end{array}$ \\
\hline Regression coefficient & 0,319798 & 0,011966 & 0,28134 & 0,362284 & 0,369457 \\
\hline Observations & 114 & 44 & 31 & 24 & 15 \\
\hline Relationship & negative & positive & negative & positive & negative \\
\hline p value & 0,000524 & 0,938554 & 0,125222 & 0,081905 & 0,17532 \\
\hline
\end{tabular}

Source: own elaboration

This paradox is clear from figure 7. We can see that high income countries with the highest knowledge index reach the lowest value of average economic growth.

Figure 7: Relation between KEI and average economic growth according to income groups of countries

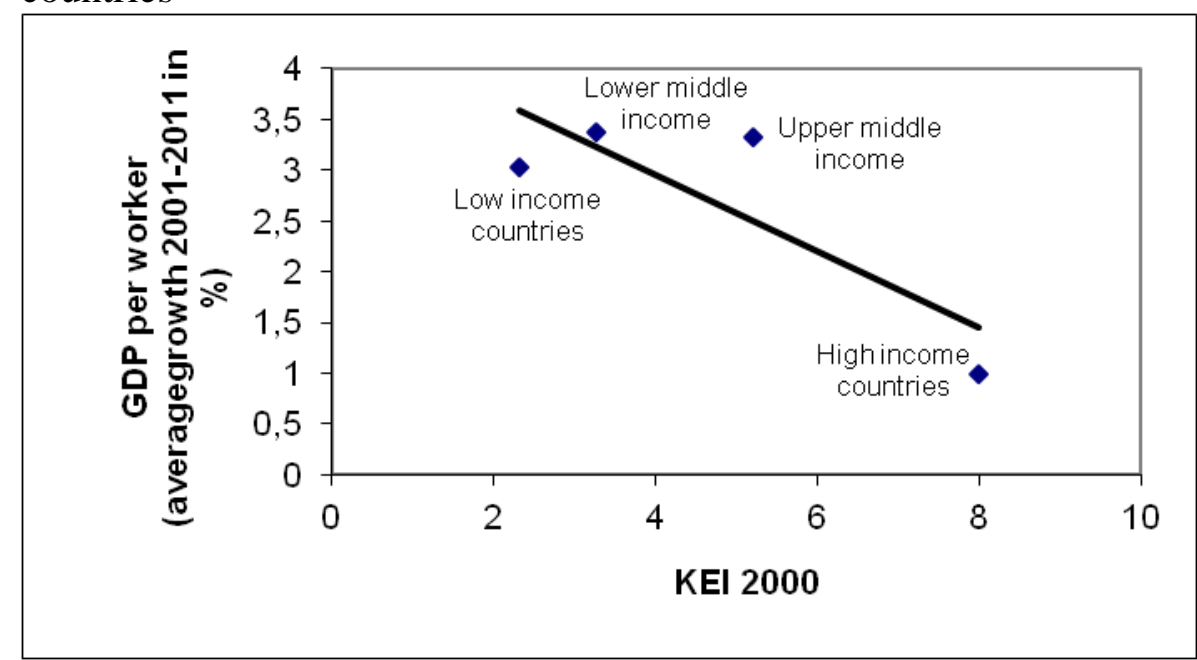

Source: www.worldbank.org, own elaboration

On the other hand low income countries and lower middle income countries are relatively at the same position, their low knowledge economy index is connected with higher rate of average growth. The reality is fully different than we expected.

\section{Conclusion}

The goal of this article was to confirm or to disconfirm two hypotheses formulated in the introduction. First hypothesis about relationship between knowledge economy and economic level was confirmed. It holds that the more investments in knowledge the country has, the more advanced it is and vice versa. Also strong correlation relationship between economic level of the country and each part of the knowledge economy index, i. e. economic and institutional regime, education, innovation and ICT, was proved. On the contrary the second hypothesis was not confirmed. It does not hold that knowledge economy will lead to higher economic growth in future. Surprisingly it was found that relationship between these two variables is negative. Especially in the group of high income countries that have the highest value of knowledge economy index, average growth measured by GDP per worker, is the lowest from all groups of the countries. The factors that could be important source of economic growth will be explored in another article. On the other hand it is very difficult to prove influence of knowledge economy on economic growth. If it is not way how to prove benefit of knowledge economy on economic growth, space for alternative accesses exists. 


\section{References}

[1] BATAGAN, L., 2008. Knowledge Dynamics and Economy Growth. Revista Informatica Economica [online]. 4(48), 27-30 [cit. 2013-02-26]. Available from: http://revistaie.ase.ro/content/48/BATAGAN\%20Lorena.pdf

[2] CSANK, P., 2008. Indikátory znalostní ekonomiky. Regionální inovační forum [online]. 13. 1. 2008 [cit. 2013-03-08]. Available from: http://www.bergmangroup.cz/ rif/indikatory-znalostni-ekonomiky

[3] KADEŘÁBKOVÁ, A., 2007. Růst, stabilita a konkurenceschopnost - III. Česká republika v globalizované a znalostni ekonomice. Praha: Linde. ISBN 80-86131-71-8.

[4] KARAGIANNIS, S., 2007. The Knowledge-Based Economy, Convergence and Economic Growth: Evidence from the European Union [online]. [cit. 2013-03-20]. Athens: Centre of planning and economic research. Available from: http://www.kepe.gr/pdf/D.P/dp_91.pdf

[5] KLAUS, V., 2012. Jak je to s "vědomostní" ekonomikou? Lidové noviny. 18. 1. 2012. ISSN 1213-1385.

[6] MATĚJŮ, P., 2001. Vzdělání a hospodářský růst. Institut pro sociální a ekonomické analýzy [online]. 5. 9. 2001 [cit. 2013-03-18]. Available from: http://www.iseacz.org/aktuality/vzdln-a-hospodsk-rst.apx

[7] NOVÁKOVÁ, J., 2011. Výzkum, vývoj a inovace v EU: přelévání znalostí a vliv tohoto procesu na tvorbu inovací. Současná Evropa [online]. 02/2011 [cit. 2013-03-08]. Available from: http://ces.vse.cz/wp-content/novakova.pdf

[8] PALIČKOVÁ, I., 2006. Problémy spojené s měřením znalostní ekonomiky. In: Znalostná ekonomika. Nové výzvy pre národohospodársku vedu. Bratislava: NHF EU. CD. ISBN 80-225-2249-X.

[9] PAULUS, M., 2011. Vliv vzdělání na HDP. Restart za lepši Česko [online]. 25. 11. 2011. Available from: http://www.czrestart.cz/vzdelani/vliv-vzdelani-na-hdp

[10] SVATOŠ, M., 2005. Globální trendy a znalostní ekonomika. Agris [online]. [cit. 201302-26]. Available from: http://www.agris.cz/content/files/main_files/70/ 148466/05svatos.pdf

[11] WORLD BANK INSTITUTE. Measuring knowledge in the world's economies. Knowledge for development program. World Bank Institute [online]. [cit. 2013-03-10] Available from: http://siteresources.worldbank.org/INTUNIKAM/Resources/ KAM_v4.pdf

[12] WORLD BANK. www.worldbank.org 